American Journal of Environmental Sciences 6 (4): 383-388, 2010

ISSN 1553-345X

(C) 2010 Science Publications

\title{
Waste Generation and Recycling: Comparison of Conventional and Industrialized Building Systems
}

\author{
Rawshan Ara Begum, Siti Khadijah Satari and Joy Jacqueline Pereira \\ Institute for Environment and Development (LESTARI), \\ University Kebangsaan Malaysia, Bangi 43600, Selangor DE, Malaysia
}

\begin{abstract}
Problem statement: In the Malaysian construction industry, there is a pressing issue of minimizing construction waste, which cause significant impacts on the environment. With the increasing demand for major infrastructure projects, commercial buildings and housing development programmers, a large amount of construction waste is being produced. Adoption of prefabrication and industrialized building systems is now a priority in the industry and also an important means of reducing waste. Approach: Discussion of the prefabrication adoption were based on a comprehensive review of literatures and studies that contained data, information, findings and evidences related to prefabrication and industrial building systems in Malaysia. This study also highlighted a comparative study of material wastage and recycling based on two project sites e.g., conventional and prefabrication construction. Results: In the Malaysia construction industry, adoption of prefabrication and IBS is strongly encouraged to reduce construction time as well as the industry's dependency on foreign workers. In addition, this study confirms that a huge amount of material wastage can be reduced by the adoption of prefabrication. This study also revealed that the rates of reused and recycled waste materials are relatively higher in projects that adopt prefabrication. Conclusion: Thus, the adoption of prefabrication and IBS has potential in the reduction of huge waste generation and management problems in the construction sector of Malaysia although there are some challenges in the adoption of prefabrication.
\end{abstract}

Key words: Waste generation, wastage and recycling, prefabrication, industrialized building systems

\section{INTRODUCTION}

The issue of minimizing construction waste which cause significant impacts on the environment is pressing for the Malaysian construction industry. With increasing demand for major infrastructure projects, commercial buildings and housing development programmers, large amounts of construction waste are being produced (Begum et al., 2009). Alshammari et al. (2008) expressed that the current environmental concerns have forced developed and developing countries to reduce air, water and land pollution for sustainable growth. Awomeso et al. (2010) also emphasized to be introduced and utilized of appropriate technologies and efficient facilities that are suitable for environmental protection. Therefore, government efforts to promote usage of Industrialized Building Systems (IBS) have been an alternative to the conventional, labor intensive and wasteful construction method. The Construction Industry Development Board of Malaysia (CIDB) has redesigned its strategies and formulated a roadmap known as the "Industrialized Building Systems (IBS) Roadmap 2003-2010”. According to the IBS Roadmap 2003-2010, IBS is a construction process that utilizes techniques, products, components or building systems which involve prefabricated components and on-site installation. Normally, this method would involve the assembly of precast elements such as floor slabs, in-filled walls, bathrooms and staircases into place for incorporation into the main units, columns and beams that reduced the amount of site lab our involved in building operations and increased the productivity of the industry. Precast building systems can reduce the duration of a project if certain conditions are met (Kadir et al., 2005). In the conventional construction method (reinforced concrete frames and brick as infill), the beam, column, wall and roof are cast in situ using timber formworks while steel reinforcement is fabricated on site. This method of construction is labor intensive and involves three separate trades, namely, steel bending, formwork fabrication and concreting (Badir et al., 2002).

Corresponding Author: Rawshan Ara Begum, Institute for Environment and Development (LESTARI), University Kebangsaan Malaysia, Bangi 43600, Selangor DE, Malaysia 
Prefabricated building components are widespread in the country. From the structural classification, the following five main IBS groups are identified which are used popularly in Malaysia (CIDB, 2003a; IBS DIGEST, 2007):

- Pre-cast Concrete Framing, Panel and Box Systems-pre-cast columns, beams, slabs, 3-D components (balconies, staircases, toilets, lift chambers) and permanent concrete formwork

- Steel Formwork Systems-tunnel forms, Expanded Polystyrene (EPS) forms, beams and columns molding forms and permanent steel formworks (metal decks)

- Steel Framing Systems-steel beams and columns, portal frames and roof trusses

- Prefabricated Timber Framing Systems-timber frames and roof trusses

- Block Work Systems-interlocking Concrete Masonry Units (CMU) and light weight concrete blocks

Adoption of prefabrication and IBS is now a priority in the industry and also an important means of reducing waste. This study provides an overview of adoption of prefabrication including its advantages and difficulties. It also highlights a comparative study of material wastage and recycling in conventional and prefabrication construction.

\section{MATERIALS AND METHODS}

Discussion of the prefabrication adoption are based on a comprehensive review of literatures and studies that contained data, information, findings and evidences related to prefabrication and industrial building systems in Malaysia. This study also highlighted a comparative study of material wastage and recycling based on two project sites e.g., conventional and prefabrication construction. The conventional project site (Kamsis H) is a non-residential/institutional building (completed in 2004) located in University Kebangsaan Malaysia (UKM), Bangi and Selangor (Fig. 1). Begum et al. (2006) demonstrated a detailed study on waste characterization and economic feasibility based on this site. Figure 2 shows a location of the prefabrication/IBS construction project site of the residential building in Parcel 7, Presint 9, Putrajaya (completed in 2008). Both the project sites were selected because they involved conventional and prefabrication building and construction activities.

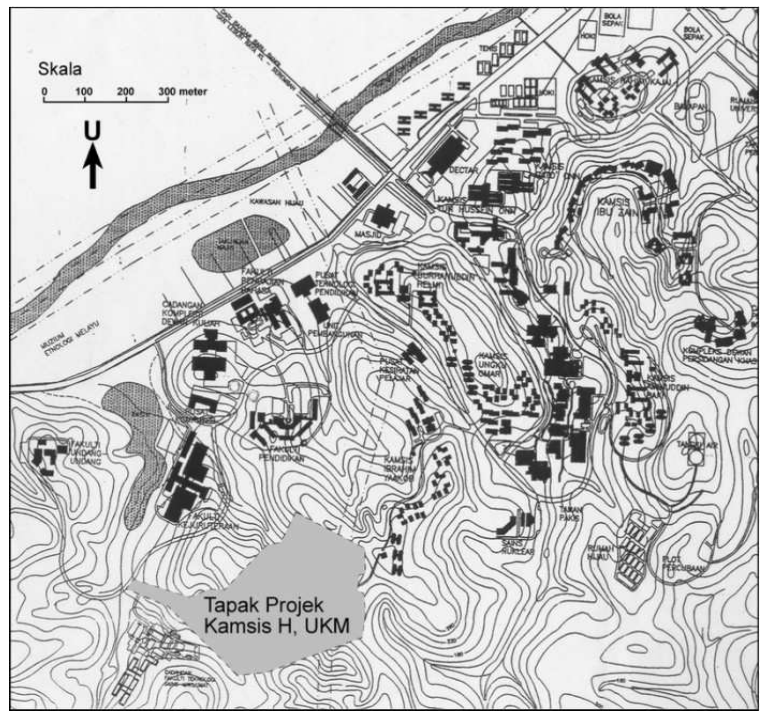

Fig. 1: Map of the conventional project site in UKM, Bangi

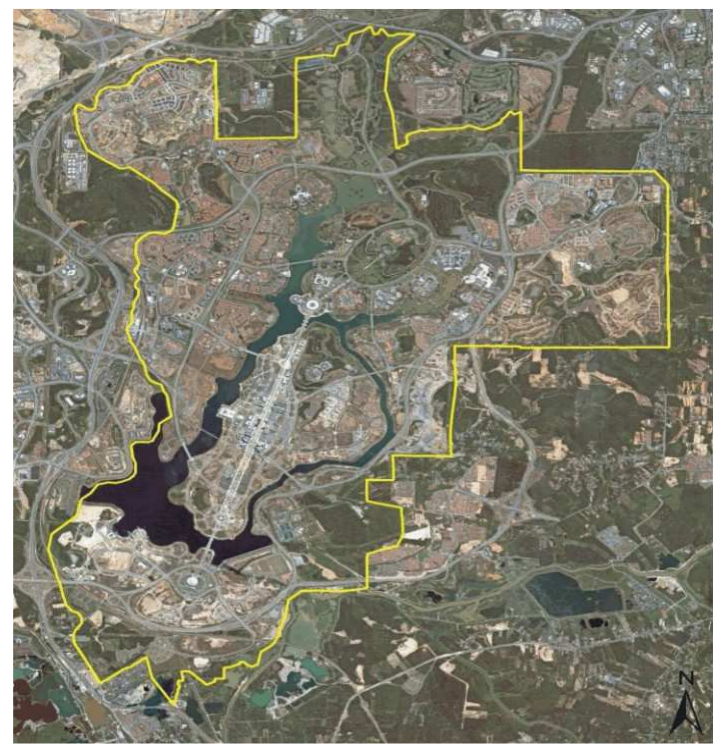

Fig. 2: Map of the IBS project site in Parcel 7, Presint 9, Putrajaya

Information and data were collected through interviews (using questionnaire) with 2-3 years of monitoring throughout the project duration, in conjunction with the developer, contractor, subcontractor, project manager, quantity surveyor and site supervisor. It should be noted that this study takes into account only on-site waste generation, composition and recycling. The study has a limitation. For the prefabricated construction project site, it did not include 
data from off-site or the precast plant. The study is based on a conservative method of estimation using gross waste generation in tonnage. Nevertheless, the study is useful as it shows a comparison of material wastage and recycling from a conventional and an IBS or fully prefabricated project site.

\section{RESULTS}

Material wastage and recycling comparison: Table 1 shows the composition and amount of waste generated from the IBS and conventional project sites. The composition of the waste is similar while its proportion differs. The largest components of waste materials are concrete and aggregate, soil and sand and brick and blocks. The total waste generated is very much higher in the conventional project i.e., 54.6 tones $100 \mathrm{~m}^{-2}$ compared to the prefabricated/IBS project of 1.5 tones $100 \mathrm{~m}^{-2}$. The huge difference in waste generation is similar to findings from other studies such as Tam et al. (2007) and Poon et al. (2001).

Table 2 shows the amount of reused and recycled waste materials from the IBS and conventional project sites. Based on the total waste generated at each site, it is observed that $94 \%$ of waste generated at the IBS site is reused and recycled compared to only $73 \%$ at the conventional project site. For the both sites, the most frequently reused and recycled materials are concrete and aggregate, soil and sand, wood as well as brick and blocks. It was noticed that a majority of the metal waste generated was removed to another project site and this is not accounted for this analysis. The study shows that there is good practice in reusing and recycling of construction waste materials on the IBS site compared to the conventional. Tam et al. (2007) also demonstrated that the adoption of prefabricated building components can effectively reduce waste generation and improve the environmental performance for overall site conditions.

\section{DISCUSSION}

Adoption of prefabrication in Malaysia: Prefabricated construction in Malaysia started almost forty years ago with the completion of the Tunku Abdul Rahman Public Housing Estate; or commonly known as the Pekeliling Flats. For the last four decades, the construction industry has been experimenting with various prefabricated construction; being lead by various precast concrete solution providers that come and go (IBS DIGEST, 2007). Tothe transformation of the Malaysian construction sector with inputs from industry based on the 5-M strategy (manpower, materialscomponents-machines, management-recesses-methods, monetary and marketing) with the target of having an industrialized construction industry and achieving Open Building by the year 2010 (CIDB, 2003c).

Table 1: Waste generation and composition: comparison between an IBS and a Conventional project, normalized to $100 \mathrm{~m}^{2}$ of floor space

\begin{tabular}{lll} 
& Amount of waste generated by weight (tones $100 \mathrm{~m}^{-2}$ floor space) \\
Construction waste materials & Fully prefabricated & Conventional \\
\hline Soil and sand & 1.01 & 14.700 \\
Brick and blocks & 0.04 & 0.6300 \\
Concrete and aggregate & 0.27 & 36.000 \\
Tiles & 0.02 & 2.7200 \\
Scrap metal & 0.01 & 0.4500 \\
Wood & 0.04 & 0.1100 \\
Plastic materials & 0.01 & 0.0300 \\
Packaging products & 0.07 & 0.0020 \\
Total & 1.47 & 54.642 \\
\hline
\end{tabular}

Table 2: Reused and recycled waste materials: comparison an IBS and a conventional project

Amount of reused and recycled waste by weight (tones)

\begin{tabular}{lcc} 
Construction waste materials fully & Prefabricated (Gross floor space: $\left.49662 \mathrm{~m}^{2}\right)$ & Conventional $\left(\right.$ Gross floor space: $\left.116,666 \mathrm{~m}^{2}\right)$ \\
\hline Soil & 1.095 & 5400.0 \\
Sand & 86.500 & \\
Concrete and aggregate & 320.000 & 13365.0 \\
Scrap metal & 12.100 & 54.0 \\
Brick and blocks & 42.030 & 126.0 \\
Roofing materials (tiles) & 22.500 & 5.4 \\
Wood & 51.900 & 810.0 \\
Total amount of reused and recycled & $1,630.030$ & 19760.4 \\
total waste generation based on gross & & 27068.4 \\
Floor space & 1729.700 & $73.0 \%$ \\
Percentage of reused and recycled & $94.240 \%$ &
\end{tabular}


Am. J. Environ. Sci., 6 (4): 383-388, 2010

Table 3: Targeted usage of IBS in Government building projects

\begin{tabular}{ll}
\hline Year & Targeted Usage of IBS (\%) \\
\hline 2005 & 40 \\
2006 & 50 \\
2007 & 60 \\
2008 & 70 \\
2009 & 80 \\
2010 & 90 \\
\hline
\end{tabular}

Source: CIDB (2003a)

The transformation of the construction sector is crucial in ensuring the successful achievement of Vision 2020 (IBS DIGEST, 2007).

The Ninth Malaysia Plan (2006) also emphasized the use of alternative construction material and technology under the IBS and designs based on the modular coordination concept in housing construction. The plan also initiates the use of IBS components in the construction of affordable homes and in Government building projects and enforcement on the use of modular coordination concept through Uniformed Building By-Laws (UBBL) by the local authorities (CIDB, 2003c; Ninth Malaysia Plan, 2006). A number of encouragement and regulatory requirements have been put forward for the utilization of IBS. An example of such regulatory requirement is the implementation of minimum percentage of IBS utilization requirement in government building projects. Similarly, minimum percentage of IBS utilization requirement is also needed for CIDB Levy exemptions. Housing developers, who utilize IBS components exceeding $50 \%$, will be given full exemption on levy imposed by (CIDB, 2003a). Table 3 shows percentage of the targeted usage of IBS in Government building projects in Malaysia.

In the Malaysian construction industry, the use of IBS as a method of construction is evolving (Kamar et al., 2007). With the advancement of technology and innovation, various prefabricated materials have entered the market including gypsum, wood wool, polymer, fiberglass, glass and aluminum-based IBS components. Currently a total of 128 IBS companies have registered with CIDB Malaysia (IBS DIGEST, 2007). More local manufacturers have established themselves in the market. As a result pre-cast, steel frame and other IBS were used as hybrid construction methods to build national landmarks such as the Bukit Jalil Sport Complex, Light Rail Transit System (LRT), Petronas Twin Towers, Putrajaya, Kuala Lumpur Central and Kuala Lumpur International Airport. It was reported that at least 21 manufactures and suppliers of IBS are actively promoting their systems in Malaysia (Kamar et al., 2007). The establishment of the IBS Centre at Jalan Chan Sow Lin, Cheras, Kuala Lumpur has also provided an impetus to the IBS agenda.
However, it appears that the usage of IBS or fully prefabrication in Malaysia is still low compared to that of other developed countries such as Japan, United Kingdom, Australia and United States of America (CIDB, 2003b). It seems a loss for the local industry players as IBS offers solutions to various issues which would definitely exert a major impact on the industry's productivity, quality, health and safety, as well as the environment. The adoption of prefabrication assures valuable advantages and difficulties to implement IBS in the construction industry of Malaysia. The following advantages have been identified of applying prefabrication in the building and construction activities (IBS DIGEST, 2007; Tam et al., 2007; CIDB, 2003b; Badir et al., 2002; Ho, 2001; Hassim et al., 2009):

- Reduction of unskilled workers

- Less waste generation

- Reduction of foreign workers employed in the construction sector that will also reduce the amount of remittance by the foreign workers (for the case of Malaysia)

- $\quad$ Reduce construction cost effectively by adopting prefabrication and mass production of building components

- Frozen or fixed design at the early stage of design for the adoption of prefabrication

- Better supervision on improving the quality of prefabricated products

- Reduce overall construction costs e.g., material and labor cost savings

- Promote safer and more organized construction site

- Improve environmental performance through waste minimization

- Enhance integrity on the building design and construction

The advantages of adopting prefabrication are accompanied by several challenges (IBS DIGEST, 2007; Tam et al., 2007; CIDB, 2003b; Badir et al., 2002; Ho, 2001; Hassim et al., 2009). These are as follows:

- Inflexible for changes of design-sometimes consultants and clients are reluctant to adopt prefabrication for the previous projects, since the design has not frozen in the development stage, which will affect adoption of prefabrication and environmental awareness for various construction parties

- Highly capital intensive or higher initial construction cost

- Lack of information based on research 
Am. J. Environ. Sci., 6 (4): 383-388, 2010

- Time consuming for the initial design development

- Limited site space for placing prefabricated building components

- Leakage problems that will occur while joining the prefabrication

- Lack of contractors or labor experience on the prefabrication

- Lack of demand for prefabricated building components

- Need for expert labor and also need for training the semiskilled labor force for highly skilled jobs

- Lack of awareness among architects, engineers, developers and contractors

\section{CONCLUSION}

Adoption of prefabrication and many prefabricated building components is not new in the construction sector of Malaysia. The application of floor and roof slab, wall panel, staircase, load bearing block, sandwich panel, timber and steel frame are the most common practices for construction activities which can effectively reduce waste generation and improve environmental performance of the construction site. However, it appears that the usage of IBS in buildings is still low. A survey conducted by CIDB (2003b) shows that the usage level of IBS in the local construction industry stands at only $15 \%$.

In the Malaysia construction industry, adoption of prefabrication and IBS is strongly encouraged to reduce construction time as well as the industry's dependency on foreign workers. In addition, this study confirms that a huge amount of material wastage can be reduced by the adoption of prefabrication. This study also reveals that the rates of reused and recycled waste materials are relatively higher in projects that adopt prefabrication. Thus, the adoption of prefabrication and IBS has potential in the reduction of huge waste generation and management problems in the construction sector of Malaysia although there are some challenges in the adoption of prefabrication.

\section{ACKNOWLEDGEMENT}

This study is part of the research project entitled "Materials Security and Waste Management for Industrialized Building Systems (IBS)" funded by the Construction Research Institute of Malaysia. We are grateful to Mr. Suresh Kumar Lachimpadi from Putra Jaya Holdings Sdn Bhd for helping during data collection and also wish to thank the contractors and their staff for providing information and data. An earlier version of this article was presented at the 2nd Construction Industry Research Achievement International Conference (CIRAIC), Kuala Lumpur, 3-5 November 2009.

\section{REFERENCES}

Alshammari, J.S., F.K. Gad, A.A.M. Elgibaly and A.R. Khan, 2008. A typical case study: Solid waste management in petroleum refineries. Am. J. Environ. $\quad$ Sci., $\quad 4$ : 397-405. http://www.scipub.org/fulltext/ajes/ajes44397-405.pdf

Awomeso, J.A., A.M. Taiwo, A.M. Gbadebo and A.O. Arimoro, 2010. Waste disposal and pollution management in urban areas: A workable remedy for the environment in developing countries. Am. J. Environ. Sci., 6: 26-32. http://www.scipub.org/fulltext/ajes/ajes6126-32.pdf

Badir, Y.F., M.R.A. Kadir and A.H. Hashim, 2002. Industrialized building systems construction in Malaysia. J. Archit. Eng., 8: 19-23. DOI: 10.1061/(ASCE)1076-0431(2002)8:1(19)

Begum, R.A., C. Siwar, J.J. Pereira and A.H. Jaafar, 2006. A benefit-cost analysis on the economic feasibility of construction waste minimization: The case of Malaysia. Resour. Conserv. Recycl., 48: 86-98. DOI: 10.1016/j.resconrec.2006.01.004

Begum, R.A., C. Siwar, J.J. Pereira and A.H. Jaafar, 2009. Attitude and behavioral factors in waste management in the construction industry of Malaysia. Resour. Conserv. Recycl., 53: 321-328. DOI: 10.1016/j.resconrec.2009.01.005

CIDB, 2003a. IBS Roadmap 2003-2010. Construction Industry Development Board of Malaysia (CIDB). http://www.cidb.gov.my/v6/?q=en/content/ibscentre/ibs-roadmap-2003-2010

CIDB, 2003b. Survey on the Usage of Industrialized Building Systems (IBS) in Malaysian Construction Industry. Construction Industry Development Board of Malaysia (CIDB). http://www.cidb.gov.my/v6/files/IBSSurvey03.pdf

CIDB, 2003c. Construction Industry Master Plan 20062015. Construction Industry Development Board of Malaysia (CIDB). http://www.cream.com.my/publications/cimp.pdf

Hassim, S., M.S. Jaafar and S.A.A.H. Sazalli, 2009. The contractor perception towers industrialized building system risk in construction projects in Malaysia. Am. J. Applied Sci., 6: 937-942. http://www.scipub.org/fulltext/ajas/ajas65937-942.pdf

Ho, O.S.T., 2001. Construction waste management-a contractor's perspective. The Hong Kong Institute of Builders. 
IBS DIGEST, 2007. IBS DIGEST @ malbex IBS DIGEST special issue for the 24th. Malaysian International Building Exposition (MALBEX). Kuala Lumpur Convention Centre. http://www.ibscentre.com.my/ibsweb/components/ com_publication/assets/uploads/file/IBS\%20Digest -malbex\%202007.pdf

Kadir, M.R.A., W.P. Lee, M.S. Jaafar, S.M. Sapuan and A.A.A. Ali, 2005. Performance comparison between structural element of building systems in Malaysia. Am. J. Applied Sci., 2: 1014-1024. http://www.scipub.org/fulltext/ajas/ajas2510141024.pdf

Kamar, K.A.M., Z.A. Hamid, M.K. Ghani and A.H. Rahim, 2007. Industrialized building system: current shortcomings and the vital role. Rand D. Master Builders.
Ninth Malaysia Plan, 2006. Ninth Malaysia Plan 20062010. The Economic Planning Unit. http://www.parlimen.gov.my/news/engucapan_rmk9.pdf

Poon, C.S., A.T.W. Yu and L.H. Ng, 2001. A guide for managing and minimizing building and demolition waste. Hong Kong Polytechnic University.

Tam, V.W.Y., C.M. Tam, S.X. Zeng and W.C.Y. Ng, 2007. Towards adoption of prefabrication in construction. Build. Environ., 42: 3642-3654. DOI: 10.1016/j.buildenv.2006.10.003 